\title{
Kontestasi Local Knowledge And Modern Scientific Swine Breeders Biak-Numfor Regency
}

\author{
Mariana Sarlota Pangurian \\ Mahasiwa PDIS Pascasarjana, \\ Universitas Cenderawasih
}

\begin{abstract}
ABSTRAK
The purpose of the study to analyze the existence of local knowledge breeder pigs and its reunion with Modern knowledge in Biak Numfor-. Research methods: this research use the paradigm of Constructivism which discourse and knowledge are seen as social reality. Reality dikontruksi in a given context and social life, is exploratory, theory was born and developed in the field, more emphasis on meaning and value as well as relying on accuracy in the collection of data to uncover the circumstances that Indeed in the field appropriately. The approach used is qualitative. Result of discussion: first, a pig breeder pattern is done mainly by the local population/ethnic population Breeds based local wisdom culture of Biak inherited hereditarylike maintenance, how the selection of the original Pig breeds, how to feeding available in nature, how prevention and treatment with the use of basic materials such as different types of leaves, fruit, bark, seaweed and sea cucumber is local wisdom contained and provided by nature in the amount will never run out. Second, is the pattern of pig breeders are made on the basis of Modern Knowledge. The pattern of these hog farms more done by breeders of pigs originating from outside of New Guinea pig breeders, i.e. from Manado, Batak, Toraja by way of maintenance with the enclosure of the cement, the selection of seed feeding pigs to race, so from the factory or a mixture of bran, remains of food stalls and the ways of prevention and treatment of chemical medicines used comes from the factory with medical or paramedical personnel. Third, is the pattern of kontestasi knowledge at level of local households, local communities, local government and the local market going positive response and the response was negative. Summary: the system of the local community (local societal system) responding to the occurrence of kontestasi between the local knowledge with modern scientific developments in hog farms in Biak-Numfor. The pattern of kontestasi knowledge at level of local households, local communities, local government and the local market going positive response and the response was negative.The most accepted patterns and responded positively to the local community of the whole system of 12 rancher i.e. is the select pattern of the coexistence of 9 second i.e. breeders knowledge takes place when there is a shared presence without mutual influence in the kontestasi between narrative meaning the same breeder will wear both knowledge while 3 breeders choose zero sum game pattern takes place when there is mutually nullify in kontestasi between narrative meaning a breeder would choose use one of the two dominant knowledge.
\end{abstract}

Key words: Kontestasi, local knowledge, modern knowledge, pig breeders

\section{INTRODUCTION}

Development of the farm is very related to the development of a region. As one Papua Province in Indonesia has considerable potential in the development of animal husbandry. It can be referred to as pig barns, with the capability of supplying cattle to other areas in order to procure cattle nationwide. The success of the construction of farms rely heavily how science and advanced technology may be adopted by the community breeders. Indonesia as a developing country has a lot of absorbing technology from developed countries, some showed good results but some other less in accordance with existing conditions Titilola (1990), noting 
that the transfer of technology from developed countries to developing countries could hamper the development of local technologies and creates dependency. Program development technological innovation must be exactly in accordance with the specific constraints such associal and environmental conditions. The application of technology that is not paying attention to the social conditions and only pay attention to ecological factors instead of damaging the environment.

Otherwise in the Community own breeders actually being there is original or indigenous technology technology (IT) as belonging to a community that already applied and fused with local cultures (Warren, 1992, and the Adnyana et al. 2000). The importance of indigenous technology expressed by Titilola (1990) that only one thing could help efforts increased income breeders with an understanding of local knowledge systems and the structure of the existing kelembagaannya. Indigenous technology is already based on experience and experimentation that repeated according the ability society. The community easily implement native technology because the input is relatively low, the risk is small and eco-friendly, while the introduction of technologies generally use high inputs, risk and often inhospitable environment (De Walt, 1994).

Kontestasi pattern between local knowledge and everyday experience are constructed based on modern knowledge of the scientific method is based are very complex.The complexity spawned three alternative reconstruction of knowledge described by Salman (2006) as reconstruction of patterned, namely; (1) the zero sum game in progress when it happens mutually nullify in kontestasi between narration, (2) hybridization took place when mixing and bore the features of new knowledge in the kontestasi between narration; reconstruction of patterned (3) coexistence takes place when there is a presence together without mutual influence in kontestasi between narrative.

The results of the field that has been done before, factually that technology introduction of research results has been much socialized and tested developed through agricultural development programs. All programs mengintroduksikan technology for increased production and the income of the farmer/rancher. Technology diintroduksikan've been through testing in a laboratory experiment, the garden or in the land of farmers/ranchers (on farm research) and calculated the feasibility of its economy before it developed into a wider community (FAO, 1994). The fact remains that a lot of technology introduction that hasn't adopted the farmer/rancher in a sustainable way (De Walt, 1994).

Among ranchers own evolving knowledge possessed hereditary which is the inheritance of his fathers and has been such a long time is applied in the management of his ranch. They have a selection of seeds by way of knowledge just tracing the appearance of such cattle. As for the marriage of natural mating. Meet the needs of livestock feed, especially during the dry season, where insufficient forage grass needs feeding, they utilize plant trees around his home environment which is then given to livestock. Likewise, in the management of disease control, most breeders utilize existing plants in the vicinity. Marketing management, local knowledge of farmers still dominate the new knowledge that is introduced, because farmers generally still do livestock sales by simply estimate the livestock performan-based pricing is not based on the weight of the cattle.

Throughout the course of time, the pig breeders have long enough and have sufficient experience in managing and grow his cattle business. The venture is managed with cultural values and specific knowledge of local produce. They act in a rational manner and apply local livestock management that fits perfectly with its environment. In addition to local knowledge 
produced themselves, they also adopt and apply other knowledge from outside that are transmitted by the agricultural extension officers/farm.

A blend of local knowledge that has long been owned by the Community farmer/rancher with scientific knowledge introduced from the outside will cause changes and response for the system of local government, i.e., the locality of the local market, komintas local breeders and to the household breeders.

Pig farm system still traditional social system is local in the face of harmony with nature is essential to review, especially in the face of global issues. It is also related to the existence of local knowledge when local knowledge with modern scientific berkontestasi into one solution in resolving the problems that become global issues.

Based on explanation above, I feel the importance of research on kontestasi local knowledge and modern scientific swine breeders in Biak-Numfor, because looking at the pros and cons of each of both the knowledge Community pig breeders living in Biak Numfor can make a choice from the results of the kotenstasi using one or both of them or there is a new feature as a way of raising pigs is good according to them.

Traditional knowledge owned by a society obtained through the experience of living in a certain place related human relationships with the environment as an ecological knowledge in the broad sense. Pig cattle business have the group by society as a hereditary system forming their knowledge through experience and a variety of experiments so that it is a process that is adaptive to the environment around. The adaptation capability make this local knowledge was able to survive until now.

The introduction of knowledge from outside the Biak Numfor Regency society has done, from the nursery aspect concerns the selection of seeds, the reproductive system, aspects relating to feed processing plant sweet-ubian, waste management market household waste, waste, food, as well as aspects of management including management and disease control and perkandangan capital. The cattle business is traditionally a positive impact against the kelanggengan social values and culture with the local wisdom has been rooted in the community, on the other hand business development cattle exposed to the various constraints, particularly over the function of the land Agriculture, lack of utilization of the environment, lack of technical personnel in the field of animal husbandry, ranging bergesernya tribal traditions byak carry out ceremonies wor, these constraints affect the ability of the production and reproduction of pigs. Interaction between knowledge of experiential/traditional/local owned by local rancher and modern scientific knowledge//global diintroduksikan from the outside. This research focuses on the kontestasi between modern knowledge with local knowledge in the context of the local system of societal dynamics (local societal system)-based livelihoods of farm.

Based on the background of the problem, then the purpose of the research is to analyze the existence of local knowledge breeder pigs and its reunion with modern knowledge which comes from outside the community as follows 1). to describe analytically local knowledge systems taxonomy (indigenous knowledge) and the application of such local knowledge systems on the production process of breeding pigs in the Biak-Numfor. 2.) Describes the pattern of kontestasi between local knowledge systems with modern knowledge systems. 3.) Describes the local community-system response (locality system; local community system, the local government system, local market system and local household system) against the 
kontestasi between local knowledge systems with modern knowledge in development of hog farms in the Biak-Numfor.

\section{REVIEW OF THE LITERATURE}

According to Foucault (2012) the archaeological Knowledge approach used to look at a system of thought, or in terms of discursive formations called Foucault (better known as "discourse"). Discourse/knowledge to form and reconstruct certain events, and the combination of these events form a narrative that can be recognized. In a society there is usually a range of discourse/knowledge are different from each other, but the power to select and support specific knowledge/discourse so that the discourse became dominant, whereas the other discourse discourse will marginalized (be marginalized) or hidden (submerged).

Foucault (2012) argued that human, knowledge, and truth is the production of the dominance relationship inherent in the plurality of relations of power. According to him the subject did not arise from a vacuum but arises from the relation of domination that is in the vicinity. A wide range of discourse/existing knowledge and distinctive not only reflect or presented the entities and social relationships, but also reconstruct or establish it. Furthermore it is said that the formation of discourse and knowledge were sourced from the community or from outside the community can be presented through the dissemination of knowledge that distributes or discourse process selection, control, and ekslusi ( the removal) that preserve the regime of truth, including at the institutional level of knowledge.

As expressed by Pieterse (1995), that globalization thus gave rise to heterogeneity of the global community in this world. The existence of globalization automatically resulted in new developments. Pieterse mengkonsepkan impacts of globalization through hybridization, global mélange , creolization, orientalisasi and also the mestizaje.

Globalisation try to immerse the old things (in this case dispesifikkan its) joined together to form new cultural forms that follow the progression so that it will appear a new cultural forms. Hybridisation can also be supported by the existence of the migration will move into a new community of a society that has a different culture. However, it expressed concern about the existence of Pieterse melting is due to the presence of globalisation empty patriotism can trigger the demographics of a person against a culture of origin (Pieterse, 1995). Hybridization or synergy is a form of fusion of an old form that is separated from the place of origin, then combined with new forms in new implementations as well.

The fusion of the old forms combined with new forms in line with the image of Long (2001) regarding the ' battlefield ' knowledge or "battlefield of knowledge" which was chosen to convey the idea at kontestasi arena in which understanding, interest and values meaningful actors against one another. In this case the intervention into the main, though not exclusively because of the dilemma of knowledge and controversy also formed the writing and analysis of policy documents and reports. In addition the research findings also struggled over the meaning and practice of social progress, which is not limited to local or scene is framed by certain institutional arrangements such as development projects or broader policy program. Interaction-interaction is not limited by the ' recipient ' and ' executor ', but embrace a wide range of committed social offender.

Associated with the docking between the two knowledge, Salman (2006) holds when local variables are increasingly interacting with a non local variable, then the knowledge being applied not only produced by the village, but also the knowledge that comes from outside . Such a situation is that transmission, cooperation, mutual cf., rivalry and conflict between the 
substance and the manufacturer and producer of knowledge takes place. The overall phenomenon this is referred to as the kontestasi of knowledge.

Kontestasi pattern between local knowledge and everyday experience are constructed based on modern knowledge of the scientific method is based are very complex.The complexity spawned three alternative reconstruction of knowledge described by Salman (2006) as reconstruction of patterned, namely; (1) the zero sum game in progress when it happens mutually nullify in kontestasi between narration, (2) hybridization took place when mixing and bore the features of new knowledge in the kontestasi between narration; reconstruction of patterned (3) coexistence takes place when there is a presence together without mutual influence in kontestasi between narrative.

The results of the field that has been done before, factually that technology introduction of research results has been much socialized and tested developed through agricultural development programs. All programs mengintroduksikan technology for increased production and the income of the farmer/rancher. Technology diintroduksikan've been through testing in a laboratory experiment, the garden or in the land of farmers/ranchers (on farm research) and calculated the feasibility of its economy before it developed into a wider community (FAO, 1994). The fact remains that a lot of technology introduction that hasn't adopted the farmer/rancher in a sustainable way (De Walt, 1994).

\section{RESEARCH METHODS.}

This research is secondary data taken from official government publication that is provincial and District animal husbandry Office, agricultural extension, District, village, kampong

Methods of analysis in this research is qualitative Research, there are at least five types of analysis techniques that are widely used namely (1) the observations involved; (2) analysis of conversation; (3) analysis of discourse; (4) analysis of the content; and (5) the ethnographic data retrieval. In the study done by analysis techniques;

\section{RESEARCH RESULTS}

\section{An analytical taxonomy of local knowledge systems (indigenous knowledge) and the application of such local knowledge systems on the production process of breeding pigs in the Biak-Numfor}

\section{historical perspective and meaning knowledge of Raising Pigs in The Culture Of People Of Biak historical perspective}

Archaeological findings indicate that pigs have been present in New Guinea (Guinea) about 6,000 to 10,000 years ago (Bulmer, S 1996; White and Allen 1980; Bulmer, S 1982; White with O'Connel in 1982, Robin Hide 2003:12) and in the introduksikan by the Austranesia. Linguistically, Biak language used by ethnic Breed is one of the languages of the Papuan language family are categorized in Austranesia (Muller 1876-1888; Wurn \& Hattori 1982 in Mansoben, 2003). This indicates that people already know the breeds of cattle pigs through their ancestors long ago. The introduction of the longer forms of experience and knowledge is accumulative. The more knowledge manifests in the mythology of the breeds of pig's role as a mediator between the natural real with the supernatural, pig-raising practices, as well as the function of a pig in the social life of the people of Biak as on the explanations have been described inthe previous chapter above. 


\section{The symbol of the Pig in the culture of Biak}

Various cultures in Melanesia in General and on culture-culture in the land of Papuain particular, we encounter a function of pigs in different facets of people's lives. Functions of the pig appears in the world of symbolism as well as in the life of sisio-the politics and economics of various ethnics in the land of Papua. The function of the symbolism of the pig, for example in the ethnic culture of Yali, as narrated in the mitologinya, is the creator of man and nature (see Siegfrid Zollner, 2011:42 -46). Other ethnic cultures such as in Mountainous Regency Ngalum people stars, there are also similar mite narrating about human relationships with pigs, where humans transformed into pigs for slaughter in the inauguration ceremony a new home. Likewise in the culture of the people of Lani, pigs have important functions as an instrument of peace, as a symbol of power and as a medium to connect with its ancestor (Mersyah, 2014).

Culture in Biak Numfor-ethnics, the function of the symbolism of pigs appeared on the role of the pig as a mediator to pass secrets about life in another world after this life in this world is ephemeral. Another part of the story that shows the symbol of the mite pigs about enforcement of the values of love and justice in society. In the mite narrated that the awarding of the pig head of kampung in lieu of his promise to marry younger women with Mananmakeri maintained by the character Mananmakeri was slain and his flesh was eaten by the citizens of the locale without giving partly to its owner. The action was causing residents to leave his community community Mananmakeri the votes have no value love and has no value honesty against him as the owner of the pig (Kamma, Kamma and 1972 in Mnubepiom, 2009). The symbolic meaning in the mite is a source of inspiration and simultaneously form the instrument of legitimacy or political as charter, as expressed by b. Malinowski (1942), for a variety of social movements that occurred in the area of culture Biak Numfor Regency since past to the present. Social movements it is eschatological natifistik, adaptive, eschatological liberation movement and the movement of new religious teachings orpembentukakan which is a mixture of elements of indigenous religions with evangelism. About social movements has been conducted scientific studies conducted by f. ch. Kamma for his dissertation entitled Koreri Messianic Movement in Biak Numfor Culture Area (1972), and the works of E.H. Rumansara entitled religious system People Breed; Acculturation, transformation and Sinkritisme (2013). Power mite which originated from the discovery of the world of eternal Mananmakeri through pig role as mediator is still alive among some people of Biak-Numfor, cultured either living on the islands of Biak Numfor and berdiaspora to various other places in The land of Papua to the present. The role of pigs in the mite that causes now, adherents of the teachings of the Religion of the people of Biak doesn't eat pork, because they believe that eating pork causes character Mananmakeri will not return to bring Koreri (Eternal Life) for the breed.

The pig is a symbol of a key multivokal in the Kaulong definition of humanity. According to the behavior of individuals, both pig and human are placed along a continuum that is marked in the extreme by the characteristic is the characteristic "pig" which are inhumane, and on the other by the characteristics of the human being "ideological" the famous. Interdependence between pigs and humans to keep humanity in inhumane world explored in depth and in the context of ritual and nonritual, expanding our understanding of the meaning of pig in Papua outside symbols of wealth that can be transacted. And power and as an element of ecological rituals.

\section{The pattern of Raising Pigs in the culture of Those breeds.}

The introduction of pigs as livestock through the long and long history as a previous explanation above is causing growing experience and knowledge systems that form the local wisdom in the culture of people of the breeds of pig-raising ways , starting from the selection of 
seeds, how to feed, how to prevent and cure pig diseases and pain, as well as how to generate good quality pig.

Comparing the patterns of cattle pigs elsewhere in the land of Papua, especially in the mountainous area of Central (Jayawijaya) is intensive with the pattern of raising pigs in the culture of the people, then we find that in the Breed is still done on a sideline with use family labor only. Suratiyah (2007) mendefinsikan this system as family farming.

The selection of nursery pigs stem Stud and done carefully because they believe that it is wrong to choose seeds then their efforts will be less successful. How to choose a tough Stud views of his performance, with respect to a normal pelirnya fruit, most of his performances of his siblings at birth. Carrier females ever seen from his descendants and his appearance at the time of birth, the parent is not deformed by looking at the nipple and around the semetris and there are six pairs. According to those observing alone is not enough, they should see the note regarding the achievement of good pig stem age pigs, the number of children who are born during the litter and how to take care of his son, pig stem an heavy pigs. All this is done to find out the type of pig is good or bad, what type of pigs and so forth need appraisal in order to be able to choose the pigs in accordance with what the purpose of the maintenance. According to informant pig skin color also affects the price of pigs as sold. If the buyer is the pig brothers who come from an area in the mountains so they will buy the original black pork because it is part of the terms of their custom and it is believed the original pork with black skin color it feels much more comfortable being in the compare the livestock of pigs with other colors. People Breed their own sometimes prefer color loreng loreng-but generally they do not dispute the color of pork.Cutting and eating the pigs normally associated with important events such as the traditional ceremony of some people Breed among others the hair clippers razor/ceremony (Wor Kapapnik), the ceremony of giving/wearing clothes (Wor Famarmar), wedding ceremony (Wor Yakyaker Farbakbuk), and others. The function of the pigs in the various ceremonies such as this is done also in other cultures in the land of Papua in people such as Dani. Cut and eat a pig is always attached to an important social events, such as the cremation ceremony, marriage, and the ceremony of initiation. The opportunity to eat the pigs most often repeated is the cremation ceremony on. Another unique opportunity where everyone either men or women or children eat pork for several weeks in a row is on the big pig Party held at regular intervals. Pork is eaten usually within weeks because of the large number of hogs that were cut during the ceremony.

The maintenance of pigs in a manner on mornings after the pigs were fed after it was off all day until the evening of the new pig back into the enclosure. The purpose of the livestock of pigs off in order to get extra food in appropriate description of the informants in this study, that the granting of this type of food knowledge also makes conditions more healthy pigs for not closeted tailored to needs the pigs. Kinds of food which feed there is usually the natural environment around them. The gardens took the results to humans and the remaining is used to feed cattle, hogs, thus feeding to livestock of pigs are no longer needed. This type of feed is composed of ubi-ubian, betatas, fruits and leaves of papaya leaves, fruit, stems and leaves of taro, coconuts, sago, fish waste and old household. In addition they also provide stem sprouts, stem spinach and mustard greens. Now they also use rice (raskin) as foodstuffs pigs. In the tradition of people, food or feed is usually cooked the first new fed to cattle, pigs, unless there is some foods such as dried coconut, papaya leaves, papaya fruit already ranum, leaf betatas, bananas, sweet crude This is not cooked but chopped and then mixed with other types of food that was already cooked and or given separately for food directly to pigs. 
Feeding in one day is given twice in the morning and the afternoon is usually done by a family member that is the father, mother and children interchangeably depending on who is there is time because sometimes the father went into the sea and mother go to the garden or vice versa if the children came home from school already. Pig food cooking tasks most performed by mothers, the food is cooked with the use of pots by number of pigs are kept. If the number of pigs is rather a lot then it can also Cook food hogs using a drum cut by dividing the two. Food is cooked using a wood stove fire. The container that is used to fill the pot in the form of food not used anymore or food which is made of wood in the form of brass rod (called saer in Biaklanguage) or the skin of the bia.

The tradition of keeping pigs, people usually keep the Breed of pigs in a sum not much. The number of pigs reared in one family mostly tail ranges from 1 to 5 with the main purpose of the tail kept the pig is in the interest of consumption in traditional ceremony such as wedding ceremonies, event initiation and others. The time now is there's a tendency to keep the pig in an amount more because the purpose of keeping the pigs not only for traditional ceremony but for the benefit of the market. This can be exemplified from observations in this study where several breeders of pigs in the Noemfoor like Mr. Elisha Sroyer 24 keeping pigs and Mr. Fredik Manggaprouw which has 39 tail.

Drinking water given indefinitely because according to informants of water is essential for digesting food and water also provided not purchased in the environment they are good water comes from wells, rain water or sea water (salt water).

The pattern of maintenance pigs in the tradition of people Breed compared to patterns of maintenance pigs in rural areas in Papua New Guinea are very different. The difference i.e. traditions Breed though their pigs off but its owner is concerned with taking the pig food remnants from the garden after human harvest. They look for the fish to adequate nutritional needs of cattle pigs and maintain health by giving the leaves, bark tetentu good disease prevention or treatment efforts with ancestral recipes used hereditary. Pattern maintenance hog farms in rural Papua New Guinea that is they let pigs searching for food alone in the Woods all day without being given additional food, even if pigs got extra food that is not adequate and if there excess so not routinely given owner. Area at the PNG only, sweet food for pigs which are always available. There is a tendency of some writers to give the information to the extent where pigs at the Central Highlands depend on food provided by a livestock Keeper them (Weiner 1988:31; Baldwin 1990:243). The 1970s, Copland and Malynicz indicates that livestock feed rations given by the keeper of the swine a plateau made by pig keeper but by no means enough to produce nutritious animal either. Copland compared his health Status (in terms of biochemical and hematologic parameters)of pigs raised in the village of exotic pigs. Indicates that the first value is lower than on the latter for some key parameters and interpreting differences This is due to the chronic poor nutrition status of pigs bred in the village (Copland 1976a; Copland 1976b). Determine the size of the average Ration of shortterm survey using a sample of households or small pig is clearly problematic source of variation may be large and includes, most importantly, the size and composition of households, the ratio the pig against the people, the State of food supplies, and state the purpose of the production of pigs. The State of the last pig production purposes there is a connection with food rations might happen varies during the cycle Bowers (1968:93) noted that in the Upper Valley Kaugel (Western Highlands Province), pig receiving extra food per day as the cycle Exchange of pigs almost done instead, Bragginton (1975:44) reported that, in the Valley of the Bra (Eastern Highlands Province), the additional amount of pigs in a population of prefestival means any pig tails gets a little fodder. The more extreme is the area of Siane (Chimbu), where Salisbury (1975:131) reported that no sweet potato forage was given to pigs in villages who 
have just completed the Festival pig: pig apparently depends only on forage alone. Furthermore, with the increase of commodity economy of the village in recent years, the possibility of pig fodder (small and broken tubers) are now often change hands with cash, as reported in the Valley of the Asaro in Indonesia 1994-95 (Benediktsson 1998:169).

S. Hylkema stated about the role of pigs in the community: "Although Ngalum, in connection with a pig, not a usual thing, held at regular intervals. Pork is indeed useful to people, but in addition those willing to make herself is credited against the pig: pig is respected. Often most of the way to farm join defined by the presence of pigs. The existence of these pigs make people guarding the location where they plant batatas (sweet potato) which is their main food while the entire rest of the Valley was reserved for hogs which he freely around and mengaisi. " Tribes and tribal NgalumDani else during the day pigs running loose on the outside and looking for food by yourself. The night they were given food batatas brought women from the garden in the courtyard or on the Silimo swine in complex silimo. Modern farms use antibiotics as growth boosters (growth promoters) is usually given as a numerical feed (feed additive) which is beneficial for increasing production (especially poultry and swine) and reduce the cost of feed (Martinez, 2009).

The benefits of using antibiotics in the feed is as follows: antibiotics indirectly affects the growth of microorganisms destroyer substances in feed and stimulate the growth of microorganisms forming amino acids, antibiotics can kill or inhibit the pathogenic microorganisms in the gastrointestinal tract, antibiotics can increase the absorption of calcium, phosphorus and magnesium from the animal feed consumed. Antibiotics can reduce the need for nutritional substances such as vitamin B12, minerals and amino acids (Siregar 1990). The use of antibiotics as feed affixes can improve livestock production so that it can pursue the desired target fast-growing dairy farmers and pig can cut faster than normal, but on the other hand the use of antibiotics can cause some problems for human health. According to the informant that Papua has been doing non Community maintenance pigs with the shortcuts as they use a very dubious short maintenance for the people of Papua, why is this so because from their observations of the maintenance of pigs they are just 7 months to 9 months.

When compared with local pork, junghuhnpattern is quite different, why? Because when it purchased modern pig to eat then it would seem his skin in the form of fat stored in skin carry quite soggy and it tasted as good as no ideal of edible swine original additionally according to informant society have become accustomed to eating pork the savory and according to informants in our satisfaction problems usually enjoy pork belly because of the very different and people have grown accustomed to eating pork.

How to prevent and cure the livestock of pigs from diseases and pain pig in the culture of the people of Biak already known hereditary. Disease prevention is done by looking at the changes that tejadi in nature with attention to the wind that blows on certain months and season fruits then immediately in the local ranchers already arif stamina of pigs them by giving certain leaves of the herb. Prevention of disease by administering awok, mampusen leaves, papaya leaves, leaves imbrab. Traditionally people Breed know 5 wind season, in which each wind has a name or term in the English breed. The fifth season of this wind blows alternately and erratic, and so influenced the decline of rainfall in every part of the island of Biak. The name of the fifth season of the wind: a wind that blows from the Wambarek to the West towards the East of the island of Biak, Wamurem Wind that blows from the East to the West of the island of Biak, Wambrauw Wind that blows from the South to the North of the islandof Biak, Wambrur the Wind blowing from the North towards the South of the island of Biak and the wind that blows from the direction of Wamires Southeast to the Northwest of the island of Biak. The knowledge 
of wind season is also very beneficial to the interests of the livestock especially cattle pigs in terms of disease prevention so that knowledge of the wind season into something which is common for the breed. The knowledge of wind season if not well known, would usually be fatal for those Breeds that were doing the cruise or fishing activities, because it can drift carried by the wind. Likewise with livestock business they can be stricken with the disease so as to make the mortality rate be high and the impact on local dairy farmers will suffer losses. The knowledge of wind season, now on the wane, as the younger generation began to interest not attracted by traditional knowledge in this field. Of the five types of wind seasons are known, they may know two seasons winds are considered to affect their life activity, namely the season Wambarek and Wamurem season. The third type of other wind blowing season not long, because the third season only appear between season Wambarek and Wamurem. Season of Wambarek (West wind) begins to blow in October that ended in February. Wambarek season rages on around December-January. While the season Wamurem (East wind) blows began in March and ended in August. The wind that blows on the season is not so firm.

Treatment of diseases of cattle pigs given consists of basic materials such as different types of leaves, fruit, bark, seaweed and sea cucumber is local wisdom contained and provided by nature in quantities that will never run out. Treatment ways that have been described and can be seen in the previous chapter above. The use of traditional medicine or etnoveteriner by making use of natural materials in research is also done by Diana and Davis (2007) explored how the practice and knowledge of etnoveteriner that affect the use of pasture resources grazing cows in Morocco. This study reported that the Aarib region, pastoralis Morocco acted in rational ways and apply local livestock management fits perfectly with their environment is stochastic and dry. Etnoveteriner treatment is used actively, and Shepherd set up local plants to treat livestock diseases. As an example of sheeba (artemisia absinthum) used for stomach worm drugs are also used in conjunction with harmel (peganum harmala) as a treatment to treat grubs in the lung and nose; both are burned together as fumigan. The drug is made from juniper (juniperus phoenica) used for uterine prolapse and retained placenta. Henna (lawsonia inermis) is applied around the wound open to accelerate the growth of skin tissue. Henna and resins from conifer trees such as juniper contain antimicrobial as well as sp. stermedia anticancer properties known to have parasites.

The types of diseases that are often found in pigs that is Vitamin A deficiency disease. Pigs who dipiara freely outside the cage (outdoor) in General never suffer from a deficiency of vitamin a. because they could easily obtain forage such as herbaceous,carotene-containing quite a lot. Carotene is in the digestive tool is converted into vitamin A, which is then stored in the liver, so that at any time the vitamins needed is ready. But for the pigs during his life dipiara in the enclosure continuously, if there is a vitamin deficiency, they could not obtain additional from the outside. Moreover, the new pigs born, reserves his vitamin A is very low, and it really depends on the Colostrum which can be received from the parent. Symptoms of vitamin A deficiency in piglet will result in still-born piglet in the womb to die, or die after birth, growth is very slow, or pot-belly (abdomen). Children of the living pig, nursed her appetite is very lacking, and the course is not normal, Piglet is born, eyeball rudimeter or blind and often piglet born prematurely (abort). On piglet growth obstacles occur, growerand in a short time become abnormal head size (large), appetite retreated, piglet become hard (stiff) and look like scaly. On pigs are great the symptoms are not so Visible, but nevertheless often result in disorders such as delayed lust or lust didn't happen at all, easy going on the inflammation of the stomach (gastrointestinal tool). Prevention is done by local ranchers, namely pigs given food forage in the form of betatas leaves, papaya leaves, the leaves of taro leaves arwam, sanje and other forage is there in the environment. The modernly usually given vitamin A, with injection 
intramuscular. If pigs exposed to a serious infection resulting from a parasite (worm) or pneumonia, then an existing vitamin A reserves rapidly running out unused or extravagant.

Anemia disease afflicting many pigs are small, around age 3 weeks. Causes mineral deficiencies, especially iron and copper. Piglet shivering cold constantly and on a humid conditions. Breast milk produced pig iron substance content of parent is very low. Symptoms of swine appear pale, especially on the earlobe and the stomach, sometimes neck became bigger, faster breathing, growth is compromised, lost weight and nimble, not many pigs lay down and pooping around where they lay. diarrhea, fecal gray or whitish yellow. Prevention can be done in a traditional society let pigs free seek and multiply the ground daily, while the pigs, dipiara in a cage, to be given land or clean brick into the enclosure. This is most easily done and cheap too. Use modern pig food to the parent awarded additional mineral containing iron and copper.Give on piglet when 24 hour tablets, mineral containing iron and cobalt. The granting of these tablets can be repeated on the day of the 7th or the 20th. The grant for the piglet can also be given a solution of iron and copper (iron-coper) which consists of 500 grams of coppersulphate grams of ferrosulphate, 75 and 3 liters of water. Putting the parent lubricated with ferrosulphate $1.8 \%$ as much as the $4 \mathrm{cc}$. Ferrosulphate reconstituted on liquid that added sugars as much as 500 grams and is given on a daily basis. It can also be a more practical and easy to do, i.e. by providing iron in the form of "iron dextran" injected as many as $100 \mathrm{mg}$ on the third day after the pig was born. Injection of iron if need be on after three weeks can be repeated with smaller doses. Due to an acute Anemi may cause sudden death with. That could lead to chronic Anemi pigs suffering from scours (diarrhoea). Piglet requires iron supply on a regular basis in order to form a haemoglobine. Pigments that Appear red blood cells is the most important part in transporting 02 (oxygen) into all the tissues of the body. The purposes of the iron for every tail piglet per day is $7 \mathrm{mg}$, where water mains can only milk supply $2 \mathrm{mg}$. iron Preparation in breast milk a small number of aircraft carriers, ranging from $30-50 \mathrm{mg}$ it will be exhausted within two weeks. After two weeks time will cause the piglet will suffer from anemi, if they are not given extra iron. Should be given copper (copper substances) and vitamin B12 is also important. Every day the parent milk only contains one-fifth of twelve iron required piglet, so it was no surprise when Piglet is lacking good maintenance will always suffer from anemi. That is why each piglet has always given extra "iron dextran" as it has been .

Diseases of white scours (white diarrhoea) or scours (diarrhoea) is a symptom of the disease of enteritis due to inflammation of the digestive or intestinal tool. Scours many attack the piglet and young pigs. Know the causes and symptoms of the disease, in particular proved extremely difficult. The disease is caused by a variety of types. The disease is generally explained that accelerate the occurrence of scours: Sanitation less than perfect, the pork is always cold, moist air State, bare enclosures, food that is less qualified, less iron (anemia), the hog lot experiencing stress. Pigs older than three days suffering from scours is certainly is not due to anemia, but rather because they are too much water or milk without restrictions in granting of water. The second possibility due to infection with e. coli. This sort of issue many overwrite piglet inacute, without going scours but suddenly piglet died suddenly. That time the parentbeing lust can allow the piglet suffers scours. 3 month old pig scours that impinge on piglet that period due to anemia, or piglet given content as well as the ballpark food is outrageously high, piglet of the cold, damp conditions and no sockets in the slightest. The energy content of the ration is outrageously high and given to stem excessive amounts will cause negative effects to his children who were breast fed. Awarding ration samacam it during the week leading up to and after giving birth will cause stem milk production became too much. This event will be to the children who are being breastfed into scours. Address this, then we recommend the ration allotment needs to be fine. I.e. two three days before the litter is of up to one week after the child, the amount of food given should be limited. Sufferers of scours 
can be causeddue to the deficiency of food rations also vitamins-vitamins, especially vitamin B, $\mathrm{A}$, and E. Traditionally, this could be overcome by providing forage plants in the form of food or fruit papaya contains vitamin $\mathrm{B}, \mathrm{A}$ and $\mathrm{E}$ in the ration of food rations to the Piglet or parent. Temperature changes suddenly and extreme that is outrageously high or low is also one of the factors is the occurrence of scours, all the more when it's ventilasinya enclosure is not perfect. Changes to the food that suddenly caused a piglet that occurs suddenly will result in piglet suffered from diarhee (scours). Escherichia coli, that bacteria could enter via the umbilical cord. The little pig easily suffer from diarrhoea due to their freezing, puti floor holding damp, crappy food, or piglettoo many nursing. Symptoms i.e. dirt is a liquid that is colored white as chalk, don't want to suckle the parent appears very weak, the head of the subjugated. Prevention is done by aiming at selalalu enclosure is dry and warm, the pedestal and given latai often replaced, not to become dirty or damp due to urine.

Swine flu disease or pestilence pig is a disease most commonly referred to fear in the Classical Swine Fever (CSF), also known as Swine Fever or Hog Cholera is a diseaseof strategic (economic loss is high, the spread of cross-provincial, regional and national, threat to public health). In Indonesia there are 25 types of Infectious animal diseases Strategic (PHMS) based on a decision of the Minister of agriculture no. 4026/Kpts/OT. 140/04/2013 April 1, 2013 and one of them namely PHMS priority was Hog cholera. Hog cholera (Hog Cholera) is a highly contagious viral disease in pigs caused by a pestivirus of the Flaviviridae familly. Hog Cholera is one of the potentially pandemic viral disease the most economically damaging in pigs in the world. Many Governments in the world to respond to it very seriously and take strict control policy, which includes a compulsory vaccination policy or cutting and destruction. Virulence of diseases related to the virus strain, age and immune status of the pigs are animals. This virus is very contagious. The acute nature of the disease is a common form of young animals, chronic form of the disease and is often found in older animals. Preventive vaccination is carried out by the modernly with anti-cholera serum pig or hogcholera rovac. The territory of Papua Province began contracting the disease of hog cholera in April 2004 in Mimika regency. The disease continued to spread to other districts and to 2009 districts that Contracting is the Mimika, Jayapura, Puncak Jaya, Tolikara, Jayawijaya and Jayapura. In the year 2015 as much as 700 pigs in Nabire Regency stated positively infected hog cholera. Suspected virus causes the disease commonly called pig pestilence comes from Makassar, South Sulawesi and Manado, North Sulawesi. Head of Department of animal husbandry and animal health Papua Province, Peter Pasereng, an autonomous Office Kotaraja, Jayapura, Mon (16/2), says hog cholera response at some point in the Meepago region which covers the County of Nabire, Paniai, Dogiyai, and Deiyai. "It's obviously very troubling the communitynot only in Nabire, but in Papua. That's because the virus can spread, "said Pasereng. Hog cholera virus or pig pestilence is a serious disease in pigs. The acute nature of the disease is characterized by sudden death and transmission and high mortality. That's because the disease attacks the respiratory and digestive tool. The disease is easily moved through direct or indirect contact. Poor sanitation and hygiene undertook to simplify this infected pigs. In addition, the virus can be transmitted through food or feed, drinking water, contaminated tools virus, and also via insect or other cattle. Department of animal husbandry and animal health Nabire Regency of Papua and have isolated Nabire Regency over the past six to eight months. This is done through the instruction of Nabire Regency Regent prohibiting the shipment of livestock, both from within and outside the region. A ban on cattle intake pigs/pork/petrol from the positive areas of hog cholera was done from the years 1987 through the instruction of the Governor Heads the regional level. I Irian Jaya number 11/INSTR-GIJ/1987 and the Government of Papua Province has issued a ban on pork intake/petrol/vaccines administered in the Papua Governor's Instruction number: 2/INSTR-GUB/2014 6 October 2014 about income restrictions livestock of pigs and their 
products from areas of contracting to the free area between kabupaten/kota se province of Papua and Papua Province from the outside.

Biak-Numfor historically Hog Cholera disease free in accordance decision letter of Minister of agriculture Number 606 the year 2006 about Hog Cholera (source: annual report of the Department of animal husbandry and agriculture 2015 food crops Biak Numfor). Although the Breed is still free of Hog Cholera was historically the informant but according to Adolof Msiren of the results of personal interviews that if the State of emergency means that if in a village or a pig Breed in many sick and dying from an amount not normally or is there incurable disease then the usefulness of these animals to treat marir particularly severe illness of pigs and tough cured by other leaves. Usage is taking a branch of wood to taste and burned into charcoal after it pounded or crushed then input into pork meals are cooked. This gift given only to season pork and given a disease for pigs sick only. According to informant marir wood Adolof Msiren already been tried dozens of years ago time elderly people experiencing difficult pig disease cured. The informant further explained, that usually if other animals such as birds can eat the flowers so that the sick cured. Plant a tree if there are plants Marir among gardens and taro taro then other vegetables wouldn't grow properly can even lead to death due to this effect Marir tree hot. The informant also explain if the tree is still this felled and gummy bear dibahu without the use of clothing and human skin directly so the skin can burn or blister. Chemical content ofwhat is in this unknown Marir tree, but it is effective to prevent and cure the disease of swine flu. Therefore it is important to do the study of Pharmacology of the chemical content of just about anything that is on this tree. Knowledge about this important cause can be a contribution to disease prevention swine flu and therefore significant for public interest especially for the world of breeding pigs. The excess of the original pig namely have the staying power of the body that is much more powerful in the appeal with a pig race known communities with pig Toraja. Local pork is familiar and has been adapting to nature. The excess at the time the local pigs are experiencing pain then done treatment like the previous explanation above. An already healthy pigs can be cut and be consumed whenever because herb-herbal concoctions are given and do not need to pay attention to the time of stopping drug (withdrawal time) which uses chemical drugs such as antibiotics in modern medicine because there is no risk of going on meat residue that may harm human health.

Modern farms in the treatment of cattle pigs using antibiotics. Treatment with the use of antibiotics in animal husbandry are indeed provide benefits for animals and breeders, but can pose a risk to the health of the community if its use does not match the rule. The risk in the form of the presence of antibiotic residues in meat due to use of antibiotics that are not in accordance with the dosage and/or do not pay attention to the time of stopping drug (withdrawal time). Antibiotic residue is the origin and/or metabolitnya found in animal products and networks including the other description of the results of the residue antibiotics. So, residues in food include the original unchanged compound, metabolites and/or other konyugat. Some drug metabolites are less known or not toxic compared to his home, but some compounds known to be more toxic. The potential threat of antibiotic residues in food on health are divided three categories, namely (1) aspects of toksikologis, (2) aspects of purity and (3) aspects of imunopatologis. According to Haagsma (1988), antibiotic residues in food and their use in the field of veterinary medicine related to veterinary public health aspects, aspects of technology and environmental aspects. Aspect toksikologis, antibiotic residues are toxic against the liver, kidneys and Central hemopoitika (formation of blood). From the aspect of purity, antibiotic residues can impair mikroflora in the digestive tract and lead to the occurrence of resistance of microorganisms, which can pose a major problem in the field of human and animal health. From the aspect of imunopatologis, antibiotic residues can cause mild allergic reactions and local, can even cause a fatal shock. Next is seen from the aspect of 
technology, the presence of antibiotic residues in foodstuffs may impede or frustrate the process of fermentation. The influence of heating against the content of the residues in foodstuffs have got great attention. Warming can menginaktivasi oksitetrasiklin 5-10 and klortetrasiklin residues ppm in foodstuffs to less than $1 \mathrm{ppm}$, but the unknown nature of the two antibiotics

terinaktivasi and his products. Moats (1988) States that the term used for inactivation of loss of antimicrobial activity and did not explain about the chemical changes that occur. Based on the information in the field of veterinary public health, challenges facing the field of public health is the resistance of microorganisms due to antibiotic residues in food of animal origin. Precaution and control of antibiotic residues, among others, policy types of antibiotics in veterinary medicine (do not use the types of antibiotics that humans use for animals), surveillance of antibiotic consumption, the application of good practices throughout the food chain (from farm to table), the application of the guarantees of food safety in food of animal origin business unit, as well as the implementation of the monitoring and surveillance of antibiotic residues in food of animal origin. Original United States multinational corporate giants, opened a factory processing cocoa beans in Gresik, East Java. Companies in the field of foodstuffs, livestock, agriculture, and trade is looking at the potential that exists in Indonesia can only be developed when combining the principles of sustainability in every business that is conducted. Cargill has been operating in Indonesia since 40 years ago or since the year 1974 . The company was founded by William w. Cargill year 1865 in Iowa, United States. Feeding techniques and innovative cages, Cargill offers customers a portfolio of pork products are produced responsibly. Consumers now have greater access to information than ever before about the products and services they choose. About the food they consume, they want and expect transparency. Consumers want to know where their food comes from, how it was made, and what it contains. For many people, the findings of recent research have inspired the desire livestock protein which is produced without the use of antibiotics. These drugs, which are used primarily to prevent and treat the disease, has raised concerns among some public health advocate that the excessive use of antibiotics in cattle can produce drug-resistant bacteria that are more. These bacteria then can affect both animals as well as humans who eat meat products. Cargill responded to these concerns by keeping pigs free of antibiotics, giving customers an alternative in addition to the conventional pork products. Antibiotic-free pork processed in facilities of Cargill in Ottumwa, Iowa. These pigs are fed a vegetarian meal of corn or soybeans, following protocol to ensure feed not having contact with animal byproducts. Because a collection of pigs is not receiving antibiotics, extra care is done to safeguard their health. The disease can be transmitted from conventional farms to livestock of antibiotic-free through incoming outgoing traffic, wild animals or birds that migrate, so pigs that died from a protective difasilitas to prevent contamination. Keep livestock free of antibiotics is a challenging job, but because the monitor throughout his life any pigs, Cargill is able to closely monitor them and give a clean environment, stress-free, all-natural, which can ensure the good health of cattle without antibiotics. As a result, consumers who want to eat pork free antibiotics get high quality meat with flavor and tenderness that correspond to their expectations. Currently, Cargill kept around 27,000 pigs females that produce antibiotic-free pork, and production has reached 12,000 pigs per week. Along the line of antibiotic-free pork Cargill continues to grow, the product can be found dikemasan-retail meat packs, national restaurant chains such as Panera ${ }^{\circledR}$, and dimenu private-label from many department stores.

The growth of antibiotic-free pork demonstrates the dedication of Cargill to expandthe portfolio of his pig meat and fulfill the desires of the customers will be greater transparency in the food they consume. 


\section{kontestasi Pattern between the local knowledge with modern scientific}

Kontestasi pattern between the local knowledge that is constructed based daily experience with knowledge of modern scientific method is based are very complex. Thecomplexity spawned three alternative reconstruction of knowledge described by Salman (2006) as patterned reconstruction; namely, (1) the zero sum game in progress when it happens mutually nullify in kontestasi between narrative meaning a breederwould choose to use one of the dominant of the two, the reconstruction of knowledge, (2) patterned hybridization took place When mixing and bore the features of new knowledge in the kontestasi between narrative meaning ranchers will wear the knowledge results of local knowledge and modern foundries; reconstruction of patterned (3) coexistence takes place when there is a presence together without mutual influence in kontestasi between narrative meaning the same breeder will wear both knowledge. There are 4 subsystems namely subsystem household (household), a subsystem of Government (Administration) local (local administration), local communities (local community) and the local market (local market). Kontestasi knowledge that took place in the development of pig breeding on both (breeding), feed management, and allegedly involves the response of each local subsystems namely households, local administration (Government), local communities ( local community) and the local market (local market).

\section{The proposition of local knowledge with Modern scientific}

The proposition of modern knowledge with local knowledge, namely:

1. application of local knowledge in the practice of the development of cattle pigs in Biak Numfor Regency takes place in the context of balancing the spiritual and ritual aspects of rational calculation.

2. The application of modern knowledge held on the practice of the development of cattle pigs in Biak Numfor Regency takes place in a context dominated by rational calculation and profit orientation

3. developing local knowledge is very dynamic and experienced the process of adaptation with the knowledge from the outside which is delivered by the Government or from private parties

4. kontestasi Pattern between local knowledge and everyday experience are constructed based on modern knowledge are constructed based scientific method can give birth to two patterns that run IE zero sum game pattern (domination) and patterns of coexistence without the pattern followed by hybridization.

5. kontestasi Patterns of knowledge gives rise to positive and negative response at every level of the system, starting at the local community level to local households, local communities, local government and the local market

6. Patterns of coexistence is the pattern that best received by the local community on the system level

Teoritik implications of the research results can be seen from the

1. The results of research on the location of the study indicates the form of patterns of kontestasi which takes place in the practice of the development of cattle pigs in Biak Numfor found only 2 patterns i.e. patterns of coexistence as much as 9 breeders and the pattern of zero sum game as much as 3 breeder, While not found the formation patterns of hybridization can be seen in table 5.1 display data informant of 162 pages up to page 168. These findings are termed "Kontestasi without Hybridization". This pattern can equip the Treasury kontestasi theories of knowledge that already exists, kontestasi knowledge presented Salman (2006) that explains the three knowledge i.e. kontestasi pattern (1) patterns of coexistence (2) pattern of hybridization and zero pattern (3) sum game. 
2. Research findings related to kontestasi this knowledge enriches the views of Foucoult (2012), long (2001) and Salman (2006) that the range of knowledge that is applied in a given social reality then the transmission takes place intercultural knowledge or more commonly called the kontestasi of knowledge.

\section{SUMMARY}

1. The pattern of local knowledge on hog farms in Biak Numfor-by locals/residents still Breed ethnic-based local wisdom culture of Biak inherited hereditary. Form-based hog farms local wisdom embodied in the way of maintenance, how the selection of seedlings of native pigs, feeding way available in nature, how prevention and treatment with the use of basic materials such as different types of leaves, fruit, bark certain wood, seaweed and sea cucumber. An important finding of this study is the discovery through local knowledge cultures Breed of one type of plant specific drugs namely Marir wood to prevent swine flu. Such knowledge is important to developed to the benefit of disease prevention swine flu impacting against the health of pigs as well as the dangers of the disease to human health in General.

2. kontestasi Pattern between local knowledge systems with modern knowledge systems in the development of hog farms in the Biak-Numfor, namely local knowledge systems by the ethnic population of the breed to use local wisdom that there is contained and in provided by nature in the amount not inexhaustible and environmentally friendly. Modern knowledge in its development is a pattern of pig breeders are made on the basis of Modern Knowledge. The pattern of these hog farms more done by breeders of pigs originating from outside of New Guinea pig breeders, i.e. from Manado, Batak, Toraja and Java by way of maintenance with the enclosure of the cement, the selection of seed feeding pigs to race, so from the factory or a mixture of bran, remains of food stalls and the ways of prevention and treatment of chemical medicines used comes from the factory with medical or paramedical personnel.

3. The system of the local community (local societal system) responding to the occurrence of kontestasi between the local knowledge with modern scientific developments in hog farms in Biak-Numfor. The pattern of kontestasi knowledge at level of local households, local communities, local government and the local market going positive response and the response was negative. The most accepted patterns and responded positively to the local community of the whole system of 12 rancher i.e. is the select pattern of the coexistence of 9 second i.e. breeders knowledge takes place when there is a shared presence without mutual influence in the kontestasi betweennarrative meaning the same breeder will wear both knowledge while 3 breeders choose zero sum game pattern takes place when there is mutually nullify in kontestasi between narrative meaning a breeder would choose use one of the two dominant knowledge.

\section{Referensi}

De Walt,B.R. 1994. Using Indigenous Knowledge to Improve Agriculture and Natural Resource Management. In : Human Organization Vol.53. No. 2. Center for Latin American Studies.

FA0. 1994. Farming Systems Development. A Participatory Approach to Helping Small-scale Farmers. Food and Agriculture Organization of the United Nations. Rome.

Forsyth, T. 2004. Challenges to Local Knowledge. Training Manual "Building on Gender, Agrobiodiversity and Local Knowledge". FAO, 2004, http:www.fao.org/sd/LINKS/documentsdownload/FS10ChallengestoLK.pdf .

Foucault, M. 2012. Arkeologi Pengetahuan. IRCiSoD, Jogyakarta

Long, N. 2001. Development Sociology. Routledge, Newyok.

Malinowski, B.1944. A Scientific Theory of Culture and Other Essays. New York, Oxford: University Press (1944).

Malinowski, B.1944. Magic, Science, Religion and Other Essays, (1944) tahun terbit. (1925). 
Mansoben, Johz.R. 1980. Gerakan Koreri di daerah Biak antara 1938-1943. Prisma 8 Jakarta.

Mersyah, R. 2014. Desain Sistem Budi Daya Sapi Potong Berkelanjutan untuk Mendukung Pelaksanaan Otonomi Daerah di Kabupaten Bengkulu Selatan. Disertasi, Sekolah Pascasarjana, Institut Pertanian Bogor.

Pieterse, J. N. 1995. Globalization as Hybridization. dalam Global Modernities. SAGE Publication, London.

Rumansara,E.H.2013. Wor dalam Lingkaran Hidup Orang Biak. Humaniora Volume XV, No. 2/2003.

Salman, D, 2006. Belajar dari Konsep Kearifan Lokal Dalam Pengelolaan Lingkungan. Makalah, Dipresentasikan dalam seminar nasional "Tinjauan Hukum, Kajian Ekologi Ekonomi dan Pemberdayaan Masyarakat (Community Development) dalam Pengelolaan Lingkungan Hidup Republik Indonesia, Makassar, 13 Desember 2006.

Titilola, S.O. 1990. The Economic of Incorporating Indigenous Knowledge System Into Agricultural Development. A Model and Analytical Framework. In : Studies in Technology and Social Change, No.17. Iowa State University Research Foundation.

Warren. 1993. Using Indigenous Knowledge for Agriculture and Rural Development. Current Issues and Studies. In : Indigenous knowlede and Development Monitor Vol. 1 No. 1 CIKARD. 